\title{
Strategic approaches of combined electrothermal processing of coal and carbonate mineral raw materials for obtainment of highly efficient synthetic energy carriers and non-fuel products
}

\author{
Anatoly Zhukov ${ }^{1 *}$ \\ ${ }^{1}$ Far Eastern Federal University, 8 Sukhanov Str., Vladivostok city, Russia
}

\begin{abstract}
Coal gasification and the production of gaseous fuels include three principal directions related to the production of fuel gas: 1) composition and heat capacity of the produced gas; 2) gas generator structures; 3) characteristic properties of the obtained alternative product low CO content and gas toxicity, which allow making full use of this gas for domestic purposes. In industrial processes of coal conversion, the following combined technologies are used most often: - semi-coking + gasification of fixed ash (low-temperature coke); — semi-coking + hydrogenation of liquid product (tar); - gasification + synthesis of high molecular weight hydrocarbons from the produced $\mathrm{SYN}$ gas $(\mathrm{CO}+\mathrm{H})$ (Fischer-Tropsch synthesis). The choice of the layout for obtaining SLF (synthetic liquid fuel) can be based on specific conditions, the cost and quality of coal, energy supply, market conditions. The products obtained in the process of gasification and hydrogenation of coals pollute the atmosphere much less than the coal burned in electrical power plants. When implementing the organizational and technological model of innovative production, the first stage includes the following combined approaches for the processing of mineral raw materials and new products: 1. processing of carbonic mineral raw materials: calcium carbide, carbon dioxide (in a gaseous, liquid or solid state); 2. acetylene, plant growth regulators (PGRs), plant protection products (TAKAR).
\end{abstract}

The second stage includes fuel and non-fuel products: 1. synthetic ethyl alcohol (ethanol), antifreeze, ethylene glycol, dichloroethane, synthetic drying oils, acetone, etc ; 2. carbamide (urea), ammonia, nitrogen in gaseous and liquid states, methanol, gasoline,

etc.

Keywords: Strategic approaches, coal, carbonates, mineral raw materials, refining, gasification, synthetic liquid fuel, products, fuel and non-fuel products

* Corresponding author: yul25juk@mail.ru 


\section{Introduction}

Until the middle of the last century, coal resources were the basis of the world and Russian energy. Since the 1950s, due to an increase in the level of oil and gas consumption, there has been a steady decline in coal production and use. At present, the share of coals in the world energy balance constitutes on the average about 30\%. According to some calculations, the current level of oil and gas production will be preserved until the middle of the $21^{\text {st }}$ century and already beyond 2050 the demand for coal resources in the world will increase sharply. Today, coal should be considered as energotechnological raw materials and it should be used on a large scale only in a complex way, dividing its potential chemical energy into approximately equal parts between energy (electricity and heat) and chemical products. Organization of energotechnological processing of solid fuel on the basis of large-scale power engineering (thermal and, possibly, nuclear), will allow us to overcome the oil and gas crisis that awaits us in the $21^{\text {st }}$ century. Negative trends in the raw materials base of oil and gas production (the reduction of resources, while it is necessary to maintain high export supplies) require a wide and rapid introduction of new coal technologies targeted at the ecology and energy saving and multiple uses of all types of coal. The coal gasification process is multi-purpose with respect to the composition of the produced gas.

The importance of the issues of technological and economic development of the coal industry, which is a complex production and economic system associated with high costs, the availability of competing energy carriers (oil, gas, nuclear fuel), is increasing due to the need to improve the technologies of mining, combined processing and use of coal, the provision of competitive forecast and industrial reserves.

The immediacy of the problem is growing even more in connection with the strategic importance of hard and brown coal for the energy sector in Russia and all over the world, which by their geological reserves exceed significantly such major energy sources as oil and natural gas, as well as nuclear fuel and potential water resources. Coal, according to the World Coal Institute, accounts for about 90\% (according to other estimates - 60-80\%) of the energy potential of all organic mineral resources suitable for mining. It is estimated, that comparable geologic reserves of coal in the bowels on the territory of Russia are also several times higher than similar reserves of oil and gas. The Strategy for the Development of Fuel and Energy Resources of the Far Eastern Economic Region until 2020 included the following tasks: "... to explore ways of overcoming the crisis situation by developing Far Eastern coal, oil and gas deposits on the basis of progressive methods of extraction and deep chemical processing of primary raw materials, as well as the introduction of a saving regime..." In this connection, it was necessary: 1) to develop physical and technical and economic and technological models of technologies and technical means for deep, integrated processing of coal and carbonate mineral raw materials; 2) to apply electrothermal and to develop plasma ecologically safe resource and energy saving technologies for processing of coal and carbonate mineral raw materials using several modules (subsystems) to produce competitive fuel and non-fuel products $[1,2,3,4]$.

\section{The theory and methods of experimental research}

When receiving gaseous fuels, three main approaches are identified, related to the production of fuel gas, a substitute for natural gas and synthesis gas $\left(\mathrm{CO}+\mathrm{H}_{2}\right)$. The composition and heat capacity of the produced gas depends not only on the gasification regimes but also on the structure of the gas generator used. The use of fuel gas allows 
solving environmental and technological problems in power engineering, metallurgy, and other industries.

The above-mentioned processes are rarely used in pure form during the industrial introduction of brown coal refining processes. The following combined technologies are used most often:

$\begin{array}{ll}- & \text { gasification + gas burning + thermal and electric energy generation; } \\ \text { - } & \text { semi-coking + gasification of fixed ash (low-temperature coke); } \\ \text { - } & \text { semi-coking + production of adsorbents; } \\ \text { - } & \text { gemi-coking + hydrogenation of liquid product (tar); } \\ \text { - } & \text { gasification + synthesis of high molecular weight hydrocarbons from the } \\ \text { gasification }+ \text { methanol generation }+ \text { production of gasoline (Mobil } & \end{array}$

Production of liquid fuels based on Fischer-Tropsch synthesis comprises converting of various carbon compounds (natural gas, hard and brown coal, heavy oil fractions, industrial wood residue) to synthesis gas (a mixture of $\mathrm{CO}$ and $\mathrm{H}_{2}$ ) with further turning into synthetic "crude oil "- Synthoil. This is a mixture of hydrocarbons, which is divided during the subsequent processing into various types of practically environmentally friendly fuel, free from impurities of sulfur and nitrogen compounds. It is enough to add $10 \%$ of synthetic fuel to conventional diesel fuel so that diesel fuel combustion products met the environmental standards.

The composition and heat capacity of the produced gas depends not only on the gasification regimes but also on the structure of the gas generator used. The use of fuel gas allows solving environmental and technological problems in power engineering, metallurgy, and other industries. The main characteristic property of the substitute natural gas is the low content of $\mathrm{CO}$ and, consequently, relatively low toxicity, which makes it possible to use this gas for domestic purposes. Synthesis gas is used for chemical refinement into methanol, motor fuels or for hydrogen production. To produce liquid fuels directly from coal, the processes of hydrogenation, pyrolysis, and solvent liquefaction are used. Production of fuel oil (alternative product for residual fuel oil) and motor fuels requires additional application of the processes of hydroprocessing of liquid coal products in order to reduce the sulfur content and other undesirable impurities. "Coal oil", obtained in the process of catalytic hydrogenation of coal, is easy to process $[5,9]$.

The developed and patented technologies provide for a complex waste-free processing of coal and carbonate mineral raw materials with the use of several modules ensuring the production at the first stage: calcium carbide, calcium oxide, carbon dioxide; at the second stage: - calcium carbide derived products: synthetic gaseous and liquid fuels and non-fuel products.

In the new manufacturing unit for the production of carbide $\left(\mathrm{CaC}_{2}\right)$, limestone $\left(\mathrm{CaCO}_{3}\right)$ is preliminarily calcined to produce calcium oxide $(\mathrm{CaO})$ and carbon dioxide $\left(\mathrm{CO}_{2}\right)$; batch of calcium oxide $(\mathrm{CaO})$ and hard coal $(\mathrm{C})$ are used to produce calcium carbide $\left(\mathrm{CaC}_{2}\right)$. Carbon dioxide $\left(\mathrm{CO}_{2}\right)$ escaping during limestone calcination is captured by equipment for trapping of exhaust gases and converted into carbonic acid gas $\left(\mathrm{H}_{2} \mathrm{SO}_{3}\right)$. In turn, calcium carbide is processed into plant growth regulators (PGRs) and plant protection products (TAKAR).

Production of acetylene from calcium carbide causes the formation of calcium hydroxide - $\mathrm{Ca}(\mathrm{OH})_{2}$, which is used in construction, in agriculture for production of superphosphate $-\mathrm{Ca}\left(\mathrm{H}_{2} \mathrm{PO}_{4}\right)$, in water purification systems, etc. Synthesis of carbamide (urea) - $\mathrm{CO}\left(\mathrm{NH}_{2}\right)_{2}$ is possible with the participation of carbon dioxide $\left(\mathrm{CO}_{2}\right)$ by addition of ammonia $\left(\mathrm{NH}_{3}\right)$ or from calcium carbide with the use of nitrogen $\left(\mathrm{N}_{2}\right)$. At the same time, for the production of nitrogen $\left(\mathrm{N}_{2}\right)$, the separation of the air mixture is used - the 
rectification of the liquid air or the oxidation of ammonia: $4 \mathrm{NH}_{3}+3 \mathrm{O}_{2}=2 \mathrm{~N}_{2}+6 \mathrm{H}_{2} \mathrm{O}$. Carbamide (urea) is used to increase the efficiency of plant growth regulators (PGRs).

Calcium oxide, calcium carbide, acetylene, methanol, carbamide, PGRs and TAKAR fertilizers are the main derived products of coal and carbonate mineral raw materials; additional products are the following: carbonic acid gas, drinking or calcined water, calcium hydroxide. In turn, the processing of acetylene allows you to obtain: synthetic ethylene and ethyl alcohol, naphthalene, hydrogen; synthetic drying oils, chloroprene rubber. In accordance with the polymerization reaction, the following products are also produced: ethylene, polyethylene (polymer), propylene, polypropylene according to the following methods of acetylene processing $\left(\mathrm{C}_{2} \mathrm{H}_{2}\right)$ :

1) Acetaldehyde $\left(\mathrm{CH}_{3} \mathrm{CHO}\right) \rightarrow$ synthetic ethyl alcohol $\left(\mathrm{C}_{2} \mathrm{H}_{5} \mathrm{OH}\right)$;

2) Benzene $\left(\mathrm{C}_{6} \mathrm{H}_{6}\right) \rightarrow$ naphthalene $\left(\mathrm{C}_{10} \mathrm{H}_{5}\right) \rightarrow$ hydrogen $\left(\mathrm{H}_{2}\right)$;

3) Vinyl-acetylene $\left(\mathrm{CH}_{2}: \mathrm{CH} \cdot \mathrm{C}: \mathrm{CH}\right) \rightarrow$ divinyl-acetylene $\left(\mathrm{CH}_{2}: \mathrm{CH} \cdot \mathrm{C}\right.$ :

$\mathrm{C} \cdot \mathrm{CH}: \mathrm{CH}_{2}$ )

$\rightarrow$ synthetic drying oils;

4) Vinyl-acetylene $\left(\mathrm{CH}_{2}: \mathrm{CH} \cdot \mathrm{C}: \mathrm{CH}\right) \rightarrow$ chloroprene $\left(\mathrm{CH}_{2}: \mathrm{CH} \cdot \mathrm{C} \mathrm{Cl}: \mathrm{CH}_{2}\right)$ $\rightarrow$ chloroprene rubber:

5) In accordance with the polymerization reaction, the following products are also produced: ethylene

Temperature, Pressure, accelerant

$\left(\mathrm{nCH}_{2}=\mathrm{CH}_{2}\right) \rightarrow \quad\left(-\mathrm{CH}_{2}-\mathrm{CH}_{2}-\right) \mathrm{n}$ - polyethylene (polymer);

Temperature, Pressure, accelerant

1) propylene $\mathrm{nCH}_{2}=\mathrm{CH}-\mathrm{CH}_{3}$

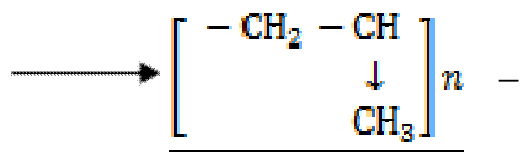

polypropylene.

\section{Results and discussion}

The results of technological researches and economic and mathematical modeling of processes allow us to consider in more detail the configuration and parameters of the systems of restructuring and diversification of coal-mining energy and industrial enterprises, to agree and determine the operating modes of control subsystems and production organization, to predict the technological and economic performance of newly created and diversified production complexes.

Picture 1 shows the example of physical and technological model of installation for the processing of coal and carbonate mineral raw materials. Similar physical and technological models are developed for the most part of products mentioned above and protected by certificates issued by authors $[7,8,9]$.

The device works the following way.

Limestone is placed in the furnace 1 and burnt. In the process of calcination, the limestone decomposes into lime and carbon dioxide $\left(\mathrm{CO}_{2}\right)$. Lime $(\mathrm{CaO})$ is removed by the product pipeline 14 to the dispenser 6 , which ensures the selection of the part of lime intended for transfer to the consumer and the part intended for further processing. Part of the lime, intended for further processing, is fed to the second furnace 2 , where in the presence of carbon (in the form of coke or hard coal, 20-25 $\mathrm{mm}$ in size and less than $1 \%$ sulfur content) is processed into calcium carbide. Calcium carbide $\left(\mathrm{CaC}_{2}\right)$ is removed by the product pipeline 14 to the dispenser 7, which ensures the selection of the part of calcium carbide intended for transfer to the consumer and the part intended for further processing. A 
portion of the calcium carbide intended for further processing is fed to the gas generator 4 where it is brought into contact with water and processed into acetylene.

The synthesis of ethanol is carried out according to a known scheme with the production of ethylene at an intermediate stage $-\mathrm{C}_{2} \mathrm{H}_{4}$ :

$$
\mathrm{C}_{2} \mathrm{H}_{2}+\mathrm{H}_{2}=\mathrm{C}_{2} \mathrm{H}_{4} ; \quad \mathrm{C}_{2} \mathrm{H}_{4}+\mathrm{H}_{2} \mathrm{O}=\mathrm{C}_{2} \mathrm{H}_{5} \mathrm{OH}
$$

Moreover, if the reaction is carried out at a pressure of up to $23 \mathrm{~atm}$ and a temperature of $75-80^{\circ} \mathrm{C}$, the yield of ethanol is up to $90 \%$, and at a pressure of up to 80 atm and a temperature of up to $280-300^{\circ} \mathrm{C}$, the ethanol yield reaches $95 \%$.

In this case, the synthesis of dichloroethane is carried out according to the following scheme:

$$
\mathrm{C}_{2} \mathrm{H}_{2}+\mathrm{H}_{2}=\mathrm{C}_{2} \mathrm{H}_{4} ; \quad \mathrm{C}_{2} \mathrm{H}_{4}+\mathrm{Cl}_{2}=\mathrm{CH}_{2} \mathrm{C} 1-\mathrm{CH}_{2} \mathrm{C} 1 \text {. }
$$

Ethylene glycol is produced by hydrolysis of acetylene.

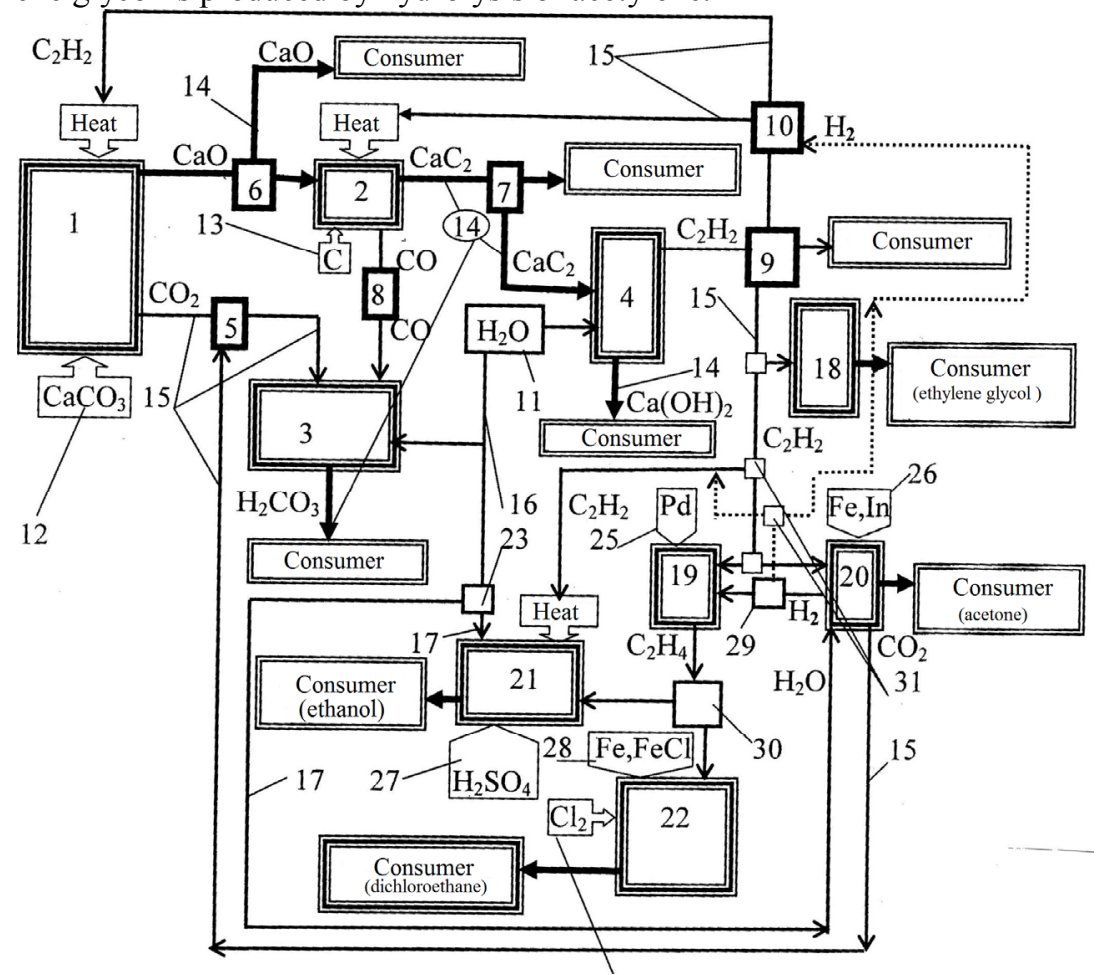

Fig. 1. Process model of the unit for the processing of coal and carbonate mineral raw materials.

The synthesis of acetone is carried out according to a known scheme, at a temperature of about $460^{\circ} \mathrm{C}$. Acetone is transferred to the consumer, and gaseous $\mathrm{C}_{2} \mathrm{H}_{2}+\mathrm{H}_{2} \mathrm{O}$ (steam) $=$ $\mathrm{H}_{3} \mathrm{C}-\mathrm{C}-\mathrm{C} \mathrm{H}_{3}+\mathrm{CO}_{2}+\mathrm{H}_{2}$ products (process sludge) are recycled locally $\left(\mathrm{CO}_{2}\right.$ is used in the production of carbonic acid gas and hydrogen - in the process of ethanol and/or dichloroethane synthesis). Hydrogen combustion is also possible, i.e. that it can be used as an energy carrier in the process of calcination or acetone synthesis, but this is not the most appropriate way to use it (the corresponding bonds are shown in dotted lines).

Thus, calcium oxide, calcium carbide, acetylene, ethanol, dichloroethane, acetone, ethylene glycol are the main products of processing of coal and carbonate mineral raw materials. As additional products, carbonic acid gas, calcium hydroxide, PGRs, and TAKAR are obtained. In case there are consumers and corresponding additional components, the main derived products from the processing of coal and carbonate mineral raw materials can be used for further processing according to the known schemes to obtain, 
for example, superphosphate, carbamide, ammonia, etc. [9].

The results of technological researches and mathematical modeling of processes allow us to consider in more detail the configuration and parameters of the systems of restructuring and diversification of coal-mining and energy enterprises, to agree and determine the operating modes of control subsystems and production organization, to predict the technological and economic performance of newly created and diversified production complexes.

In this case, optimization of production costs is carried out on the basis of the following criterion:

$$
\Pi=\Sigma_{l}^{m} \Sigma_{i}^{n}\left(c_{i}-s_{j i}\right) v_{i} \rightarrow \max
$$

where $\boldsymbol{\Pi}-$ is the total profit margin of the coal mining and energy enterprises gained due to the sale of products; $\boldsymbol{m}$ - is the number of coal ranks; $\boldsymbol{n}$ - is the number of methods of processing and use; $V_{j i}$ - is the physical quantity of coal of the rank $J$, processed and used in the $\boldsymbol{l}$ way; $\boldsymbol{S}_{j i}$ - is the production cost of coal of the rank $\boldsymbol{J}$, processed and used in the $\boldsymbol{l}$ way; $C_{\boldsymbol{i}}-$ the price of coal of the rank $\boldsymbol{J}$ and fuel of $\boldsymbol{l}$ type.

Moreover, the following restrictions are imposed:

$\mathbf{C}_{\mathrm{ji}} \leq \mathbf{C}_{\mathrm{ji}} \leq \mathbf{C}_{\mathrm{ji}}$, restrictions are established on the basis of market research;

$\mathbf{0} \leq \mathbf{V}_{\mathbf{j i}} \leq$ minimum $\left(\mathbf{v}_{\mathbf{j i}}{ }^{\text {tech. }} ; \mathbf{v}_{\mathbf{j i}}{ }^{\text {cons. }}\right.$ ), where $\mathbf{v}_{\mathbf{j i}}{ }^{\text {tech. }}$ - maximum possible volume of production; $\mathbf{v}_{\mathbf{j i}}{ }^{\text {cons. }}$ - maximum possible volume of sales.

The results of calculations of economic parameters of integrated processing of coal and carbonate mineral raw materials are carried out under the conditions of Spasskcement OJSC, Partizanskaya GRES and other industrial enterprises of Primorsky District.

When calculating the technical and economic indicators of the location of competitive production, the following indicators are identified: return on investment, production cost, sales margins, payback period, profitability index $[4,10,11]$.

\section{Conclusions}

I consider it expedient to carry out research and development works together with the Engineering School of FEFU and Institute of mining of the Far East Division of Russian Academy of Sciences for increasing the efficiency of development and use of fuel and energy resources in the following areas:

1) to develop physico-technical and economic-technological model of technologies and technical means for deep chemical stage-by-stage processing of coal and carbonate mineral raw materials;

2) to apply electrothermal and to develop plasma ecologically safe resource and energy saving technologies for processing coal and carbonate mineral raw materials using several modules (subsystems) to produce competitive fuel and non-fuel products;

3) to develop Technical Design Assignment (TDA) for the performance of R\&D (research and development), NPD (new project development), TEJ (techno-economic justification) with the solution of the following tasks: consideration of alternative options for locating the enterprises of newly designed mining and chemical complexes in Russia and abroad; to develop innovative technologies and complexes of technical means for industrial processing of coal and carbonate mineral raw materials using plasma reactors with a capacity of $500 ; 1000 \mathrm{~kW}$. 


\section{References}

1. A.P. Sorokin, G.P. Avdeyko, A.V. Alekseev, P.Ya. Baklanov, A.V. Zhukov, V.I. Podolian and others. Strategic development of fuel and energy potential of Far Eastern Economic Region till 2020, p. 112 (2001)

2. A.V. Zhukov, "Application \& Fundamental research" International journal, 12, pp. $147-150(2010)$

3. E.S. Korneeva, Master's Thesis majoring in Management., Economics and Management Institute of FESTU, p. 45 (2008)

4. E.A. Gnezdilov, A.V. Zhukov, A.D. Iakovlev, Fundamental research journal, 12(2), pp. 342-344 (2007)

5. E.A. Gnezdilov, A.V. Zhukov, Fundamental research journal, 9, pp. 61-64 (2007)

6. A.V. Zhukov, M.I. Zvonarev, Iu.A. Zhukova, Patent 74912, Bulletin 20 (2008)

7. A.V. Zhukov, M.I. Zvonarev, Iu.A. Zhukova, Patent RU 2362735 C1, Bulletin 21 (2009)

8. $\quad$ A.V. Zhukov, M.I. Zvonarev, Yu.A. Zhukova, Patent RU 2373178 C2, Billetin 32 (2009)

9. A.V. Zhukov, D.E. Kusraeva, Ia.A. Zhukova, RJPBBP-RJPBCS - Res. Jour. of Pharm., Biol. and Chem. Sciences, ISSN09758585-India-Scopus, 7(4), 2401-2414 (2016) 10. A.V. Zhukov, Mat. on All-Rus. Conf. with Intern. Part. Mult. Use of Poten. of H. and Br. Coal and Dev. of Comb. Ecol. Safe Tech. (Blagoveshchensk, Amur SC of FEB RAS, 2017)

11. A.V. Zhukov, M.I. Zhukova, Yu.A. Zhukova, A.A. Shmelev, Mat. on Intern. Scien.-Pract. Conf. Kn.-int. Tech. Dev. and Use of Min. Res., 4, 128-133 (2018) 